\title{
Auraticoccus monumenti gen. nov., sp. nov., an actinomycete isolated from a deteriorated sandstone monument
}

\author{
Pablo Alonso-Vega, Lorena Carro, Eustoquio Martínez-Molina \\ and Martha E. Trujillo
}

Correspondence

Martha E. Trujillo

mett@usal.es

\author{
Departamento de Microbiología y Genética, Edificio Departamental, Lab. 205, Campus Miguel de \\ Unamuno, Universidad de Salamanca, 37007 Salamanca, Spain
}

\begin{abstract}
A Gram-type-positive, strictly aerobic actinobacterium, designated strain MON $2.2^{\top}$, was isolated from the surface of a sandstone monument. Cells with a coccoid shape, arranged in pairs or clusters, were non-motile and did not produce spores. The 10 closest $16 \mathrm{~S}$ rRNA gene sequence matches ( $95 \%$ similarity) found in the public databases were uncultured actinobacteria, while the closest cultured members indicated a phylogenetic relationship with members of the family Propionibacteriaceae (92-95\% similarity). Subsequent phylogenetic analysis placed the new isolate within the radiation of the genera Friedmanniella and Microlunatus, but forming an independent branch. Chemotaxonomic markers were consistent with the classification of strain MON $2.2^{\top}$ in the family Propionibacteriaceae, amongst the genera containing LL-diaminopimelic acid in their peptidoglycan. Characteristic fatty acids iso- $\mathrm{C}_{15: 0}$ and anteiso- $\mathrm{C}_{15: 0}$ also supported its affiliation to this taxon; however, polar lipid and menaquinone compositions clearly

differentiated strain MON $2.2^{\top}$ from other genera in the family. On the basis of these results and additional physiological data obtained in the present study, it is proposed that strain MON $2.2^{\top}$ be classified in a novel species in a new genus, for which the name Auraticoccus monumenti gen. nov., sp. nov. is proposed. The type strain of Auraticoccus monumenti is MON $2.2^{\top}$ (=CECT $7672^{\top}=$ DSM $23257^{\top}=$ LMG $25551^{\top}$ ).
\end{abstract}

Surfaces are continuously exposed to physical, chemical and biological degradation. Among the biological agents that cause deterioration, micro-organisms play an important yet poorly understood role (Cappitelli et al., 2007). Members of the family Geodermatophilaceae have been reported previously as members of the complex microbiota that thrives on stone surfaces, including many deteriorated rock monument surfaces in the Mediterranean basin (Urzi et al., 2001). The presence of members of the Geodermatophilaceae on rock surfaces is frequently associated with orange, black and grey patinas and spots as well as with alteration of the material, such as biopitting and powdering (Urzì \& Realini, 1998). Many facades in the Old Town of Salamanca (Spain) are built with Villamayor sandstone and present many of the deterioration signs mentioned above. In order to study the occurrence of actinobacterial populations growing on these surfaces,

\footnotetext{
Abbreviation: DAP, diaminopimelic acid.
}

The GenBank/EMBL/DDBJ accession number for the 16S rRNA gene sequence of strain MON $2.2^{\top}$ is FN552748.

Three supplementary figures and a supplementary table are available with the online version of this paper. samples were collected from various monuments to isolate these bacteria.

Stone samples were taken with a sterile spatula, gently scraping the deteriorated surface, and the samples were processed immediately. Briefly, samples were ground to a powder in a sterile mortar and $1 \mathrm{~g}$ material was suspended in saline solution $(0.85 \%, \mathrm{w} / \mathrm{v}, \mathrm{NaCl})$ supplemented with Tween $80(0.001 \%, \mathrm{v} / \mathrm{v})$, in a ratio of one part powder to nine parts solution $(\mathrm{w} / \mathrm{v})$. Samples were shaken for $1 \mathrm{~h}$ at maximum setting (approx. 50 r.p.m.; Dynal sample mixer), serial dilutions were prepared (from $10^{-1}$ to $10^{-4}$ ) and plated on Luedemann agar (Luedemann, 1968) at $\mathrm{pH}$ 7.8. Strain MON $2.2^{\mathrm{T}}$ was isolated after 2 weeks of incubation at $28{ }^{\circ} \mathrm{C}$ and maintained as a pure culture in $20 \%$ glycerol $(\mathrm{v} / \mathrm{v})$ at $-80{ }^{\circ} \mathrm{C}$ for long-term preservation.

Cultural and morphological characteristics of the new isolate were determined on Geodermatophilus obscurus agar (Atlas, 1993), International Streptomyces Project 2 (ISP 2) agar (Shirling \& Gottlieb, 1966), Luedemann agar, Microlunatus agar (DSMZ medium 776) and R2YE agar (Hopwood et al., 1985) at $28{ }^{\circ} \mathrm{C}$. Cell morphology and motility were observed by phase-contrast microscopy using 3- and 7-day-old cultures (Leica; CTR MIC). Gram 
staining was done as described by Doetsch (1981). Cells of strain MON $2.2^{\mathrm{T}}$ were fixed in $2 \%(\mathrm{v} / \mathrm{v})$ glutaraldehyde in $0.05 \mathrm{M}$ cacodylate buffer, critical-point-dried and coated with gold for scanning electron microscopy (Zeiss; DSM 940). For transmission electron microscopy, a centrifuged cell-suspension pellet was fixed in $2 \%$ glutaraldehyde, post-fixed and stained with $1 \%$ osmium tetroxide, embedded in epoxy resin and examined in a Zeiss DM 900 microscope.

Strain MON $2.2^{\mathrm{T}}$ showed good growth after $4-5$ days on all media tested except R2YE agar. Diffusible pigments were not produced on any of these media. Colonies were golden orange, circular, smooth, shiny and with regular edges. Cells were Gram-stain-positive, coccus-shaped (0.8$1.2 \mu \mathrm{m})$ and non-motile and did not produce spores. The cells occurred singly and in pairs, triads or even small clusters (Supplementary Fig. S1a, available in IJSEM Online). Thin sections of the cells revealed a typical Gram-positive cell wall and showed a thick septum in the middle of the cells; two septa along the same plane were sometimes seen (Supplementary Fig. S1b). Capsules were not present around the cells.

The 16S rRNA gene of the new isolate was amplified and sequenced directly using the REDExtract-N-Amp Plant PCR kit (Sigma) and procedures described previously (Rivas et al., 2003; Trujillo et al., 2007). The DNA contig obtained (1449 nt) was compared with sequences deposited in the public databases and the EzTaxon server (Chun et al., 2007). The sequences of strain MON $2.2^{\mathrm{T}}$ and the most closely related taxa were retrieved from GenBank and aligned using the CLUSTAL_X program (Thompson et al., 1997). Phylogenetic distances were calculated with Kimura's two-parameter model (Kimura, 1980) and evolutionary trees were inferred using the maximumparsimony (Fitch, 1971), neighbour-joining (Saitou \& Nei, 1987) and maximum-likelihood (Felsenstein, 1981) methods. Phylogenetic analyses were performed using the software packages MEGA4 (Tamura et al., 2007) and ARB (Ludwig et al., 2004). Branch support based on 1000 replications was calculated to evaluate the tree topologies.

An almost-complete 16S rRNA gene sequence comprising $1449 \mathrm{nt}$ was determined for strain MON 2.2 $2^{\mathrm{T}}$. Similarity values indicated that the novel strain is a member of the family Propionibacteriaceae, with Friedmanniella lucida (95.3\% similarity to the type strain), Friedmanniella lacustris and Friedmanniella luteola (95.0\%), Microlunatus panaciterrae $(94.9 \%)$ and Friedmanniella sagamiharensis (94.8\%) being the closest cultured relatives, as calculated by the EzTaxon server. Members of the remaining genera in the family Propionibacteriaceae were less than $94 \%$ similar. When the sequence was subjected to a BLAST search against the GenBank database, 17 uncultured bacterial clones with sequence similarity of $94-95 \%$ were listed before any of the taxa mentioned above. These uncultured clones have been detected in different environments, including an endolithic sample (Supplementary Fig. S2).
A tree reconstructed using the neighbour-joining method (Fig. 1) shows the placement of strain MON 2.2 ${ }^{\mathrm{T}}$ within the radiation of the genera Friedmanniella, Microlunatus and Propionicicella supported by a bootstrap of $81 \%$. The new isolate was recovered in a single branch and was distantly related to the genus Friedmanniella, the closest phylogenetic relative. This topology was also recovered in trees reconstructed using the maximum-parsimony and maximum-likelihood methods. The assignment of strain MON $2.2^{\mathrm{T}}$ to the family Propionibacteriaceae was also supported by the presence of the $16 \mathrm{~S}$ rRNA gene sequence signatures defined for the family (Zhi et al., 2009). The DNA $\mathrm{G}+\mathrm{C}$ content, determined by the thermal meltingpoint method (Mandel \& Marmur, 1968), was $73.5 \mathrm{~mol} \%$.

Biomass for chemotaxonomic analyses was obtained by growing strain MON $2.2^{\mathrm{T}}$ in ISP 2 broth, in shaking flasks at 120 r.p.m. and $28{ }^{\circ} \mathrm{C}$ for 5 days. Peptidoglycan structure and cell-wall amino acids were determined as described before (Rhuland et al., 1955; Schleifer \& Kandler, 1972; Schleifer, 1985) by TLC on cellulose plates. Quantitative analysis of amino acids was performed, after derivatization, by GC and GC/MS according to MacKenzie (1987). Cell-wall sugar composition was determined by acid hydrolysis of cells as described by Whiton et al. (1985) and sugars were detected by TLC on cellulose plates (Staneck \& Roberts, 1974). Phospholipids and menaquinones were prepared according to the method of Minnikin et al. (1984) and analysed by twodimensional TLC and HPLC, respectively. Methyl esters of cellular fatty acids were prepared from cells grown for $24 \mathrm{~h}$ on trypticase soy broth agar (TSBA) and analysed using the MIDI system (Microbial ID, Inc.). Chemotaxonomic analyses were carried out by the Identification Service of the DSMZ.

The peptidoglycan structure of strain MON $2.2^{\mathrm{T}}$ contained the amino acids LL-diaminopimelic acid (LL-DAP), alanine, glycine and glutamic acid in an approximate ratio of $1.1: 1.7: 0.8: 1.0$. In addition to these amino acids, the partial hydrolysate contained the peptides L-Ala-D-Glu and LL-DAP-D-Ala. This structure corresponds to type A3 $\gamma$ LLDAP-Gly, according to Schleifer \& Kandler (1972). The presence of LL-DAP in the cell wall of strain MON $2.2^{\mathrm{T}}$ showed good correlation with the phylogenetic results, given that the closest phylogenetic relatives, Friedmanniella and Microlunatus (Nakamura et al., 1995; Schumann et al., 1997), also contain LL-DAP in their cell walls. In this case, the new isolate could be differentiated from members of other genera in the family Propionibacteriaceae that contain meso-DAP in their cell walls, e.g. Propionicicella, Propionicimonas and Micropruina (Shintani et al., 2000; Akasaka et al., 2003; Bae et al., 2006). The sugars found in the cell wall of strain MON $2.2^{\mathrm{T}}$ were glucose and traces of rhamnose, arabinose and xylose. The menaquinone HPLC profile of the new isolate showed the presence of unsaturated menaquinones, with MK- $8\left(\mathrm{H}_{2}\right)(56 \%)$ being the main component, followed by MK- $9\left(\mathrm{H}_{2}\right)(21 \%)$, MK-9 $\left(\mathrm{H}_{4}\right) \quad(15 \%)$ and MK- $9\left(\mathrm{H}_{0}\right) \quad(9 \%)$. The main menaquinone present in many members of the family Propionibacteriaceae is MK-9 $\left(\mathrm{H}_{4}\right)$. This molecule was also 


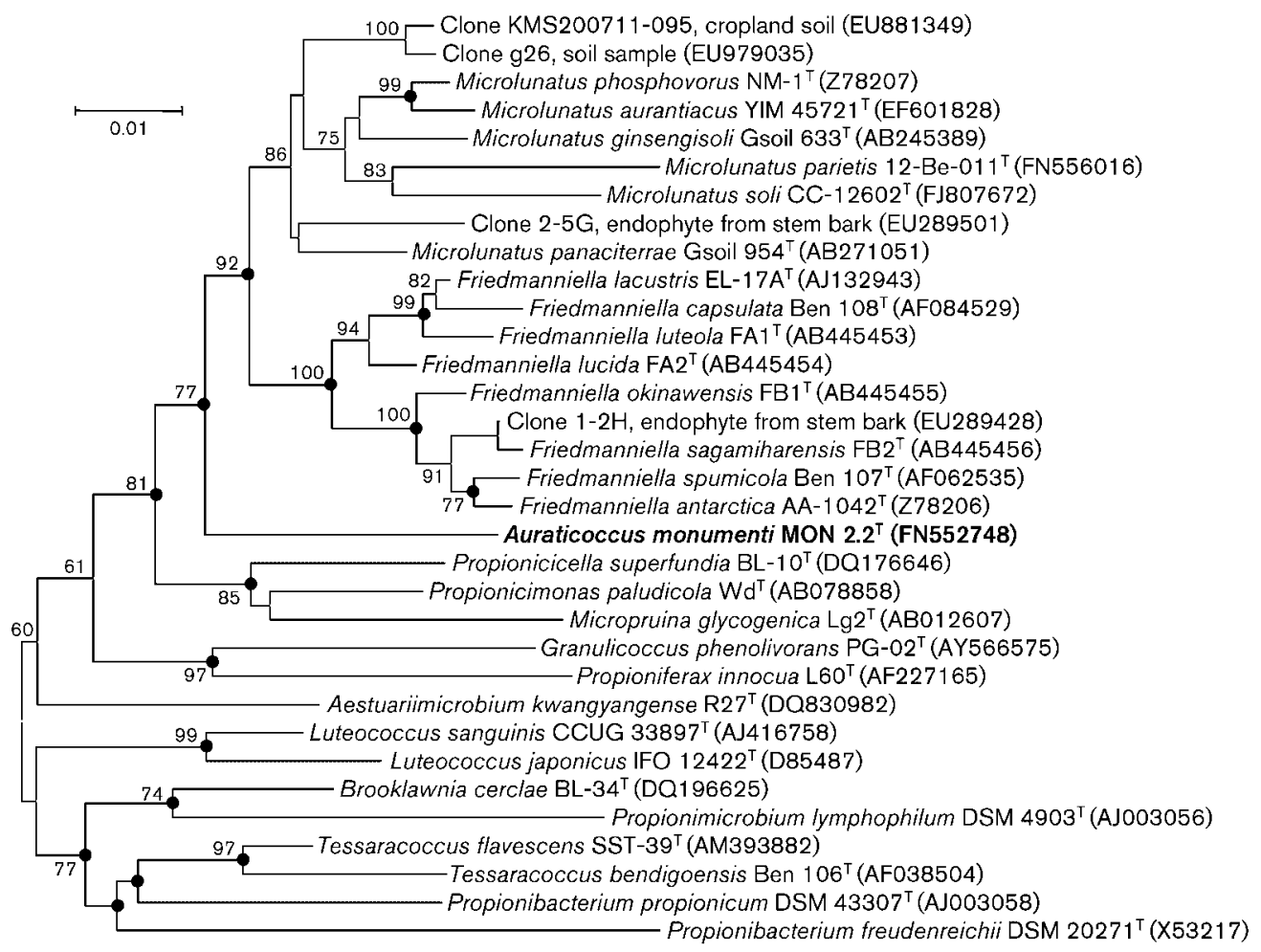

Fig. 1. $16 \mathrm{~S}$ rRNA gene sequence-based phylogeny of strain $\mathrm{MON} 2.2^{\top}$ and representative taxa in the family Propionibacteriaceae. The tree was reconstructed from distance matrices using the neighbour-joining method. Nodes also recovered with the maximum-parsimony and maximum-likelihood methods are marked by filled circles. Bootstrap values $>50 \%$ are shown. Bar, 0.01 substitutions per nucleotide position.

detected in strain MON 2.2 $2^{\mathrm{T}}$; however, MK-8 $\left(\mathrm{H}_{2}\right)$ was found in a much higher proportion. This chemotaxonomic marker may also be useful for differentiating the newly proposed genus. The phospholipid profile found in the cells of isolate MON $2.2^{\mathrm{T}}$ was very complex and was composed of phosphatidylglycerol, diphosphatidylglycerol and nine unidentified lipids: two lipids, two polar lipids, four glycolipids and one phosphoglycolipid (Table 1 and Supplementary Fig. S3). This profile was clearly different from those of other members of the family Propionibacteriaceae and readily differentiated strain MON $2.2^{\mathrm{T}}$ from members of the genera Microlunatus and Friedmanniella, which contain phosphatidylinositol. The fatty acid profile of isolate MON $2.2^{\mathrm{T}}$ contained significant amounts of branched-chain fatty acids that included anteiso- $\mathrm{C}_{15: 0}(64.2 \%)$, iso- $\mathrm{C}_{15: 0}(9.5 \%)$, anteiso- $\mathrm{C}_{15: 1}$ $(3.4 \%)$, anteiso- $\mathrm{C}_{17: 0}(3.35 \%)$ and iso- $\mathrm{C}_{14: 0}(2.0 \%)$. The complete profile from cells grown on TSBA is given in Supplementary Table S1. In summary, isolate MON $2.2^{\mathrm{T}}$ was clearly distinguishable by a combination of the above chemotaxonomic markers from other members of the family Propionibacteriaceae (Table 1).

The oxygen requirement of strain MON $2.2^{\mathrm{T}}$ was determined on ISP 2, Luedemann and Microlunatus agars by incubating plates in an anaerobic chamber (headspace $90 \% \mathrm{~N}_{2}, 5 \%$
$\mathrm{CO}_{2}$ and $5 \% \mathrm{H}_{2}$ ) at $28{ }^{\circ} \mathrm{C}$ for 3 weeks. No growth was observed under these conditions, suggesting that isolate MON $2.2^{\mathrm{T}}$ was a strictly aerobic micro-organism. The new isolate was clearly distinguishable from members of the genera Propionicicella and Propionicimonas, which are facultatively anaerobic (Akasaka et al., 2003; Bae et al., 2006).

Strain MON $2.2^{\mathrm{T}}$, Friedmanniella antarctica DSM $11053^{\mathrm{T}}$ and Microlunatus phosphovorus DSM $10555^{\mathrm{T}}$ were studied in parallel for an array of physiological and biochemical characters. Catalase was determined by bubble formation after the addition of $3 \%(\mathrm{v} / \mathrm{v})$ hydrogen peroxide. Oxidase activity was determined by oxidation of $1 \%$ tetramethyl- $p$ phenylenediamine dihydrochloride. Growth at 4, 15, 22, 25, $28,30,37$ and $45{ }^{\circ} \mathrm{C}$ and tolerance of $\mathrm{NaCl}(1,3,5$ and $7 \%$, $\mathrm{w} / \mathrm{v}$ ) were determined on Microlunatus agar for all strains. The same medium was used to determine growth at $\mathrm{pH} 4.5$, 5.5, 6.5, 7, 8 and 9; in this case, the medium was adjusted using appropriate buffer solutions (Mcllvaine, 1921; Bates \& Bower, 1956). Enzyme activities were tested with the API ZYM and API Coryne kits (bioMérieux), and carbon source utilization was examined as described by Williams et al. (1983). All tests were done under aerobic conditions at $28{ }^{\circ} \mathrm{C}$, except for temperature growth assays. Incubation time was 2 weeks for all tests except for the API ZYM and API Coryne kits, which were incubated for 1 week. 
Table 1. Differential characteristics of strain $\mathrm{MON} 2.2^{\top}$ and related taxa of the family Propionibacteriaceae

Reference strains: 1, Friedmanniella antarctica AA- $1042^{\mathrm{T}}$ (data from Schumann et al., 1997); 2, Microlunatus phosphovorus NM-1 ${ }^{\mathrm{T}}$ (Nakamura et al., 1995); 3, Propionicicella superfundia BL-10 ${ }^{\mathrm{T}}$ (Bae et al., 2006); 4, Propionicimonas paludicola $\mathrm{Wd}^{\mathrm{T}}$ (Akasaka et al., 2003); 5, Micropruina glycogenica $\operatorname{Lg} 2^{\mathrm{T}}$ (Shintani et al., 2000). ND, No data available.

\begin{tabular}{|c|c|c|c|c|c|c|}
\hline Characteristic & MON $2.2^{\mathrm{T}}$ & 1 & 2 & 3 & 4 & 5 \\
\hline Arrangement & $\begin{array}{c}\text { Single, pairs } \\
\text { or clusters }\end{array}$ & $\begin{array}{l}\text { Packets } \\
\text { and clusters }\end{array}$ & $\begin{array}{l}\text { Single or } \\
\text { pairs }\end{array}$ & ND & $\begin{array}{c}\mathrm{V} \text { or crescent } \\
\text { shape }\end{array}$ & $\begin{array}{l}\text { Single, pairs } \\
\text { or packets }\end{array}$ \\
\hline Colony colour & Golden orange & Orange & Cream & White & White & White \\
\hline Major menaquinone(s) & $8\left(\mathrm{H}_{2}\right), 9\left(\mathrm{H}_{2}\right), 9\left(\mathrm{H}_{4}\right)$ & $9\left(\mathrm{H}_{4}\right)$ & $9\left(\mathrm{H}_{4}\right)$ & $9\left(\mathrm{H}_{4}\right)$ & $9\left(\mathrm{H}_{4}\right), 10\left(\mathrm{H}_{4}\right)$ & $9\left(\mathrm{H}_{4}\right)$ \\
\hline $\begin{array}{l}\text { DAP isomer in } \\
\text { peptidoglycan }\end{array}$ & LL-DAP & LL-DAP & LL-DAP & meso-DAP & meso-DAP & meso-DAP \\
\hline Major fatty acids ${ }^{\star}$ & $\begin{array}{c}\text { ai- } C_{15: 0}, \mathrm{i}-\mathrm{C}_{15: 0} \\
\text { ai- } \mathrm{C}_{15: 1}\end{array}$ & $\begin{array}{l}\mathrm{i}-\mathrm{C}_{15: 0} \\
\text { ai- } \mathrm{C}_{15: 0}\end{array}$ & $\begin{array}{c}\mathrm{i}-\mathrm{C}_{15: 0}, \mathrm{ai}-\mathrm{C}_{15: 0} \\
\mathrm{i}-\mathrm{C}_{16: 0}\end{array}$ & $\begin{array}{c}\text { ai- } C_{15: 0}, C_{15: 0} \\
\text { i- } C_{16: 0}\end{array}$ & $\begin{array}{c}\mathrm{C}_{13: 0}, \text { ai- }-\mathrm{C}_{15: 0}, \\
\mathrm{C}_{15: 0}\end{array}$ & $\begin{array}{l}\mathrm{i}-\mathrm{C}_{14: 0} \\
\text { ai- } \mathrm{C}_{15: 0}\end{array}$ \\
\hline $\begin{array}{l}\text { DNA G }+ \text { C content } \\
(\mathrm{mol} \%)\end{array}$ & 73.5 & 73 & 67.9 & 69.9 & 68.7 & 70.5 \\
\hline
\end{tabular}

*ai, Anteiso-branched; i, iso-branched.

†DPG, Diphosphatidylglycerol; PG, phosphatidylglycerol; PI, phosphatidylinositol; GL1-GL4, unknown glycolipids; L1-L2, unknown lipids; PGL1, unknown phosphoglycolipid; PL, PL1-PL2, unknown polar lipids.

Tests for catalase and oxidase activities of strain MON 2.2 were positive. Growth was observed at $15-30{ }^{\circ} \mathrm{C}$, but not at 37 or $45{ }^{\circ} \mathrm{C}$, at $\mathrm{pH}$ 6.5-9.0, but not at $\mathrm{pH} 4.5-5.5$, and in the presence of $1-5 \%(\mathrm{w} / \mathrm{v}) \mathrm{NaCl}$ but not $7 \%$. Gelatin was hydrolysed but not urea. Nitrate reduction was negative. Results of tests for enzyme activities and carbon source utilization, including acid production from various carbohydrates, are given in Table 2 and in the species description. A combination of these tests was useful to differentiate the new isolate from the type species of the genera Friedmanniella and Microlunatus, the closest phylogenetic neighbours of strain MON 2.2 $2^{\mathrm{T}}$.

The results obtained in the taxonomic characterization of strain MON 2.2 $2^{\mathrm{T}}$, which include a distinct phylogenetic branch, unique chemotaxonomic profile and physiological data, indicate that this micro-organism is clearly differentiated from other actinobacteria in the family Propionibacteriaceae, and we propose to classify it in a new genus and species, Auraticoccus monumenti gen. nov., sp. nov.

\section{Description of Auraticoccus gen. nov.}

Auraticoccus (Au.ra.ti.coc'cus. L. adj. auratus golden; N.L. masc. n. coccus (from Gr. masc. n. kokkos a grain, seed) a coccus; N.L. masc. n. Auraticoccus golden coccus).
Colonies are golden orange, circular, smooth and shiny with regular edges. Cells are Gram-type-positive, non-motile, nonspore-forming cocci $(0.8-1.2 \mu \mathrm{m}$ in diameter). Cells may appear singly, in pairs, in triads or arranged in small clusters. Strictly aerobic and chemo-organotrophic. Catalase and oxidase are produced. Cell-wall peptidoglycan contains LLDAP. Cell-wall sugars are glucose, rhamnose, arabinose and xylose, the latter three in trace amounts. The major fatty acids are branched-chain acids anteiso- $\mathrm{C}_{15: 0}$, iso- $\mathrm{C}_{15: 0}$, anteiso$\mathrm{C}_{15: 1}$, anteiso- $\mathrm{C}_{17: 0}$ and iso- $\mathrm{C}_{14: 0}$. The menaquinones present are MK-8 $\left(\mathrm{H}_{2}\right)$, MK-9 $\left(\mathrm{H}_{2}\right)$, MK-9 $\left(\mathrm{H}_{4}\right)$ and MK$9\left(\mathrm{H}_{0}\right)$. The complex polar lipid profile includes phosphatidylglycerol, diphosphatidylglycerol and nine unidentified lipids: lipids L1 and L2, phospholipids PL1 and PL2, glycolipids GL1, GL2, GL3 and GL4 and phosphoglycolipid PGL1. On the basis of $16 \mathrm{~S}$ rRNA gene sequencing, the genus belongs to the class Actinobacteria and is most closely related to the genera Friedmanniella, Microlunatus, Propionicicella and Propionicimonas in the family Propionibacteriaceae. The DNA $\mathrm{G}+\mathrm{C}$ content of the type strain of the type species is $73.5 \mathrm{~mol} \%$. The type species is Auraticoccus monumenti.

\section{Description of Auraticoccus monumenti sp. nov.}

Auraticoccus monumenti (mo.nu.men'ti. L. gen. n. monumenti of a monument). 
Table 2. Physiological and biochemical characteristics that differentiate strain $\mathrm{MON} 2.2^{\top}$ and its closest phylogenetic neighbours

Strains: 1, MON 2.2 $2^{\mathrm{T}}$ 2, Friedmanniella antarctica DSM $11053^{\mathrm{T}}$; 3, Microlunatus phosphovorus DSM $10555^{\mathrm{T}}$. All data are from the present study. +, Positive; - , negative; w, weak.

\begin{tabular}{|c|c|c|c|}
\hline Characteristic & 1 & 2 & 3 \\
\hline Oxidase & + & - & + \\
\hline \multicolumn{4}{|l|}{ Growth at/in: } \\
\hline $4{ }^{\circ} \mathrm{C}$ & - & + & - \\
\hline $15^{\circ} \mathrm{C}$ & $\mathrm{w}$ & + & + \\
\hline $5 \%(\mathrm{w} / \mathrm{v}) \mathrm{NaCl}$ & + & - & - \\
\hline pH 6.5 & $\mathrm{w}$ & - & w \\
\hline $\mathrm{pH} 9$ & + & $\mathrm{w}$ & + \\
\hline Nitrate reduction & - & - & + \\
\hline Pyrazinamidase & - & - & + \\
\hline Urease & - & - & + \\
\hline Gelatin hydrolysis & + & - & + \\
\hline \multicolumn{4}{|l|}{ Use of carbon sources } \\
\hline L-Alanine & + & - & + \\
\hline L-Arginine & + & - & + \\
\hline L-Asparagine & $\mathrm{w}$ & - & + \\
\hline Cellulose & + & - & $\mathrm{w}$ \\
\hline Fructose & + & - & + \\
\hline Sodium gluconate & - & - & + \\
\hline L-Histidine & $\mathrm{w}$ & - & + \\
\hline L-Lysine & $\mathrm{w}$ & - & + \\
\hline Sodium propionate & - & - & + \\
\hline Raffinose & + & - & + \\
\hline L-Serine & + & - & + \\
\hline Sorbose & + & - & + \\
\hline Starch & + & - & + \\
\hline \multicolumn{4}{|l|}{ Acid from: } \\
\hline Glucose & + & - & + \\
\hline Lactose & $\mathrm{w}$ & - & + \\
\hline Maltose & $\mathrm{w}$ & - & + \\
\hline Sucrose & + & - & + \\
\hline Xylose & + & - & + \\
\hline \multicolumn{4}{|l|}{ API ZYM results } \\
\hline Esterase (C4) & $\mathrm{w}$ & - & w \\
\hline Esterase lipase (C8) & $\mathrm{w}$ & + & w \\
\hline Lipase (C14) & - & - & + \\
\hline Cystine arylamidase & $\mathrm{w}$ & - & + \\
\hline Trypsin & + & - & + \\
\hline$\alpha$-Chymotrypsin & + & - & + \\
\hline Naphthol-AS-BI-phosphohydrolase & - & $\mathrm{W}$ & - \\
\hline$\alpha$-Mannosidase & + & - & - \\
\hline$\alpha$-Fucosidase & + & - & - \\
\hline
\end{tabular}

Shows the following properties in addition to those given in the genus description. Grows at $15-30{ }^{\circ} \mathrm{C}$, with optimum growth at $28{ }^{\circ} \mathrm{C}$, at $\mathrm{pH} 6.5-9.0$ and in the presence of $1-5 \%(\mathrm{w} / \mathrm{v}) \mathrm{NaCl}$. Good growth is observed on Geodermatophilus, ISP 2, Luedemann and Microlunatus agars, but no pigments are produced on these media. Positive for hydrolysis of aesculin and gelatin and activities of alkaline phosphatase, leucine arylamidase, valine arylamidase, acid phosphatase, $\alpha$-galactosidase, $\beta$-galactosidase, $\alpha$-glucosidase, $\beta$-glucosidase and $N$-acetyl- $\beta$-glucosaminidase. Negative for activities of $\alpha$-naphthol-AS-BI-phosphohydrolase, $\beta$-glucuronidase and arginine dihydrolase and indole production. Positive for the use of the following carbon sources: amygdalin, arbutin, cellobiose, D-fructose, D-glucose, D-mannose, raffinose, galactose, inositol, lactose, maltose, mannitol, melezitose, melibiose, $\mathrm{N}$-acetylglucosamine, sucrose, salicin, trehalose, methyl $\alpha$-D-glucoside and methyl $\alpha$-D-mannoside; negative for use of 5-ketogluconate, 2-ketogluconate, adonitol, citrate, gluconate, glutaric acid, L-proline, propionic acid, quinic acid, L-tyrosine, valine and methyl $\beta$-xyloside. Acid is produced from glucose, sucrose and xylose. Additional physiological data are given in Table 2.

The type strain, MON $2.2^{\mathrm{T}}\left(=\right.$ CECT $7672^{\mathrm{T}}=$ DSM $23257^{\mathrm{T}}$ $=\mathrm{LMG} 25551^{\mathrm{T}}$ ), was isolated from a sandstone monument in Salamanca, Spain.

\section{Acknowledgements}

This work was funded by the Junta de Castilla y León (JCyL) to M.E.T. under the project SA100A7. L.C. and P.A.V. also acknowledge MICINN and the JCyL for $\mathrm{PhD}$ grants. We thank Professor J. P. Euzéby for his advice in naming the new species.

\section{References}

Akasaka, H., Ueki, A., Hanada, S., Kamagata, Y. \& Ueki, K. (2003). Propionicimonas paludicola gen. nov., sp. nov., a novel facultatively anaerobic, Gram-positive, propionate-producing bacterium isolated from plant residue in irrigated rice-field soil. Int J Syst Evol Microbiol 53, 1991-1998.

Atlas, R. M. (1993). In Handbook of Microbiological Media, p. 394. Edited by L. C. Parks. Boca Raton, FL: CRC Press.

Bae, H.-S., Moe, W. M., Yan, J., Tiago, I., da Costa, M. S. \& Rainey, F. A. (2006). Propionicicella superfundia gen. nov., sp. nov., a chlorosolvent-tolerant propionate-forming, facultative anaerobic bacterium isolated from contaminated groundwater. Syst Appl Microbiol 29, 404-413.

Bates, R. G. \& Bower, V. E. (1956). Alkaline solutions for $\mathrm{pH}$ control. Anal Chem 28, 1322-1324.

Cappitelli, F., Principi, P., Pedrazzani, R., Toniolo, L. \& Sorlini, C. (2007). Bacterial and fungal deterioration of the Milan Cathedral marble treated with protective synthetic resins. Sci Total Environ 385, 172-181.

Chun, J., Lee, J.-H., Jung, Y., Kim, M., Kim, S., Kim, B. K. \& Lim, Y. W. (2007). EzTaxon: a web-based tool for the identification of prokaryotes based on $16 \mathrm{~S}$ ribosomal RNA gene sequences. Int J Syst Evol Microbiol 57, 2259-2261.

Doetsch, R. N. (1981). Determinative methods of light microscopy. In Manual of Methods for General Bacteriology, pp. 21-33. Edited by P. Gerhardt, R. G. E. Murray, R. N. Costilow, E. W. Nester, W. A. Wood, N. R. Krieg \& G. B. Phillips. Washington, DC: American Society for Microbiology.

Felsenstein, J. (1981). Evolutionary trees from DNA sequences: a maximum likelihood approach. J Mol Evol 17, 368-376.

Fitch, W. M. (1971). Toward defining the course of evolution: minimum change for a specific tree topology. Syst Zool 20, 406-416. 
Hopwood, D. A., Bibb, M. J., Chater, F., Kieser, T., Bruton, C. J., Kieser, H. M., Lydiate, D. J., Smith, C. P., Ward, J. M. \& Schrempf, H. (1985). Genetic Manipulation in Streptomyces: a Laboratory Manual. Norwich: John Innes Foundation.

Kimura, M. (1980). A simple method for estimating evolutionary rates of base substitutions through comparative studies of nucleotide sequences. J Mol Evol 16, 111-120.

Ludwig, W., Strunk, O., Westram, R., Richter, L., Meier, H. Yadhukumar, Buchner, A., Lai, T., Steppi, S. \& other authors (2004). ARB: a software environment for sequence data. Nucleic Acids Res 32, 1363-1371.

Luedemann, G. M. (1968). Geodermatophilus, a new genus of the Dermatophilaceae (Actinomycetales). J Bacteriol 96, 1848-1858.

MacKenzie, S. L. (1987). Gas chromatographic analysis of amino acids as the $N$-heptafluorobutyryl isobutyl esters. J Assoc Off Anal Chem 70, 151-160.

Mandel, M. \& Marmur, J. (1968). Use of ultraviolet absorbance temperature profile for determining the guanine plus cytosine content of DNA. Methods Enzymol 12B, 195-206.

Mcllvaine, T. C. (1921). A buffer solution for colorimetric comparison. J Biol Chem 49, 183-186.

Minnikin, D. E., O'Donnell, A. G., Goodfellow, M., Alderson, G., Athalye, M., Schaal, K. \& Parlett, J. H. (1984). An integrated procedure for extracting bacterial isoprenoid quinones and polar lipids. J Microbiol Methods 2, 233-241.

Nakamura, K., Hiraishi, A., Yoshimi, Y., Kawaharasaki, M., Masuda, K. \& Kamagata, Y. (1995). Microlunatus phosphovorus gen. nov., sp. nov., a new gram-positive polyphosphate-accumulating bacterium isolated from activated sludge. Int J Syst Bacteriol 45, 17-22.

Rhuland, L. E., Work, E., Denman, R. F. \& Hoare, D. S. (1955). The behavior of the isomers of $\alpha, \varepsilon$-diaminopimelic acid on paper chromatograms. J Am Chem Soc 77, 4844-4846.

Rivas, R., Sánchez, M., Trujillo, M. E., Zurdo-Piñeiro, J. L., Mateos, P. F., Martínez-Molina, E. \& Velázquez, E. (2003). Xylanimonas cellulosilytica gen. nov., sp. nov., a xylanolytic bacterium isolated from a decayed tree (Ulmus nigra). Int J Syst Evol Microbiol 53, 99-103.

Saitou, N. \& Nei, M. (1987). The neighbor-joining method: a new method for reconstructing phylogenetic trees. Mol Biol Evol 4, 406425.

Schleifer, K. H. (1985). Analysis of the chemical composition and primary structure of murein. Methods Microbiol 18, 123-156.

Schleifer, K. H. \& Kandler, O. (1972). Peptidoglycan types of bacterial cell walls and their taxonomic implications. Bacteriol Rev 36, 407477.
Schumann, P., Prauser, H., Rainey, F. A., Stackebrandt, E. \& Hirsch, P. (1997). Friedmanniella antarctica gen. nov., sp. nov., an LL-diaminopimelic acid-containing actinomycete from Antarctic sandstone. Int $J$ Syst Bacteriol 47, 278-283.

Shintani, T., Liu, W. T., Hanada, S., Kamagata, Y., Miyaoka, S., Suzuki, T. \& Nakamura, K. (2000). Micropruina glycogenica gen. nov., sp. nov., a new Gram-positive glycogen-accumulating bacterium isolated from activated sludge. Int J Syst Evol Microbiol 50, 201-207.

Shirling, E. B. \& Gottlieb, D. (1966). Methods for characterization of Streptomyces species. Int J Syst Bacteriol 16, 313-340.

Staneck, J. L. \& Roberts, G. D. (1974). Simplified approach to identification of aerobic actinomycetes by thin-layer chromatography. Appl Microbiol 28, 226-231.

Tamura, K., Dudley, J., Nei, M. \& Kumar, S. (2007). MEGA4: molecular evolutionary genetics analysis (MEGA) software version 4.0. Mol Biol Evol 24, 1596-1599.

Thompson, J. D., Gibson, T. J., Plewniak, F., Jeanmougin, F. \& Higgins, D. G. (1997). The CLUSTAL_X windows interface: flexible strategies for multiple sequence alignment aided by quality analysis tools. Nucleic Acids Res 25, 4876-4882.

Trujillo, M. E., Kroppenstedt, R. M., Fernández-Molinero, C., Schumann, P. \& Martínez-Molina, E. (2007). Micromonospora lupini sp. nov. and Micromonospora saelicesensis sp. nov., isolated from root nodules of Lupinus angustifolius. Int J Syst Evol Microbiol 57, 27992804.

Urzì, C. \& Realini, M. (1998). Colour changes of Noto's calcareous sandstone as related with its colonization by microorganisms. Int Biodeter Biodegr 42, 45-54.

Urzì, C., Brusetti, L., Salamone, P., Sorlini, C., Stackebrandt, E. \& Daffonchio, D. (2001). Biodiversity of Geodermatophilaceae isolated from altered stones and monuments in the Mediterranean basin. Environ Microbiol 3, 471-479.

Whiton, R. S., Lau, P., Morgan, S. L., Gilbart, J. \& Fox, A. (1985). Modifications in the alditol acetate method for analysis of muramic acid and other neutral and amino sugars by capillary gas chromatography-mass spectrometry with selected ion monitoring. J Chromatogr A 347, 109-120.

Williams, S. T., Goodfellow, M., Alderson, G., Wellington, E. M. H., Sneath, P. H. A. \& Sackin, M. J. (1983). Numerical classification of Streptomyces and related genera. J Gen Microbiol 129, 1743-1813.

Zhi, X.-Y., Li, W.-J. \& Stackebrandt, E. (2009). An update of the structure and 16S rRNA gene sequence-based definition of higher ranks of the class Actinobacteria, with the proposal of two new suborders and four new families and emended descriptions of the existing higher taxa. Int J Syst Evol Microbiol 59, 589-608. 